\title{
Transport of Tank 241-SY-101 Waste Slurry: Effects of Dilution and Temperature on Critical Pipeline Velocity
}

K.P. Recknagle

Y. Onishi

May 1999

Prepared for the U.S. Department of Energy under Contract DE-AC06-76RLO 1830

Pacific Northwest National Laboratory

Richland, Washington 99532 


\section{DISCLAIMER}

This report was prepared as an account of work sponsored by an agency of the United States Government. Neither the United States Government nor any agency thereof, nor any of their employees, make any warranty, express or implied, or assumes any legal liability or responsibility for the accuracy, completeness, or usefulness of any information, apparatus, product, or process disclosed, or represents that its use would not infringe privately owned rights. Reference herein to any specific commercial product, process, or service by trade name, trademark, manufacturer, or otherwise does not necessarily constitute or imply its endorsement, recommendation, or favoring by the United States Government or any agency thereof. The views and opinions of authors expressed herein do not necessarily state or reflect those of the United States Government or any agency thereof. 


\section{DISCLAIMER}

Portions of this document may be illegible in electronic image products. Images are produced from the best available original document. 


\section{Summary}

This report presents the methods and results of calculations performed to predict the critical velocity and pressure drop required for the two-inch pipeline transfer of solid/liquid waste slurry from underground waste storage Tank 241-SY-101 to Tank 241-SY-102 at the Hanford Site. The effects of temperature and dilution on the critical velocity were included in the analysis. These analyses show that Tank 241-SY-101 slurry should be diluted with water prior to delivery to Tank 241-SY-102. A dilution ratio of 1:1 is desirable and would allow the waste to be delivered at a critical velocity of $1.5 \mathrm{ft} / \mathrm{sec}$. The system will be operated at a flow velocity of $6 \mathrm{ft} / \mathrm{sec}$ or greater; therefore, this velocity will be sufficient to maintain a stable slurry delivery through the pipeline. The effect of temperature on the critical velocity is not a limiting factor when the slurry is diluted 1:1 with water. Pressure drop at the critical velocity would be approximately two feet for a $125-\mathrm{ft}$ pipeline (or 250 -ft equivalent straight pipeline). At $6 \mathrm{ft} / \mathrm{sec}$, the pressure drop would be 20 feet over a 250 -ft equivalent straight pipeline. 



\section{Contents}

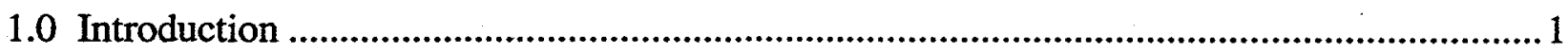

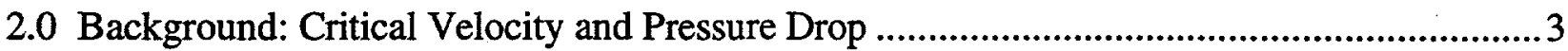

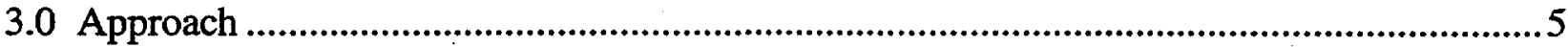

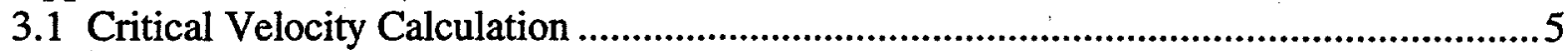

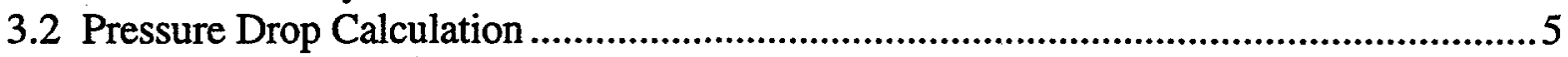

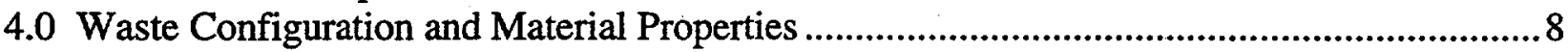

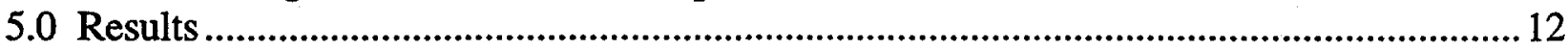

6.0 Conclusions and Recommendations ............................................................................... 14

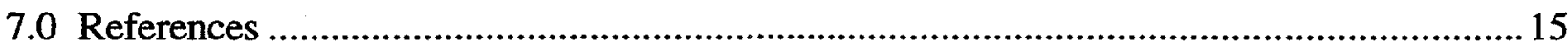

Appendix A: Methods Used to Calculate the Critical Velocity ……………….............................. A.1

Appendix B: Pressure Drop Calculation—the Wasp Method...................................................... B.1

\section{Figures}

1 Estimated Yield Point versus Solid Concentration.........................................................................

2 Estimated Yield Point of Non-Diluted Slurry versus Temperature................................................

\section{Tables}

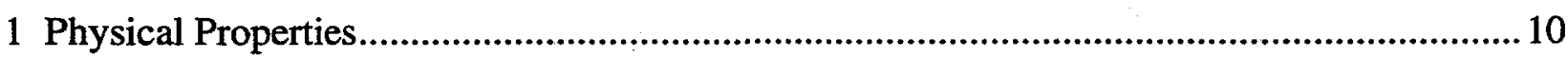

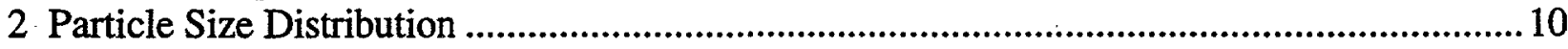

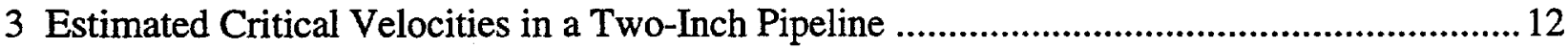

4 Estimated Pressure Drops and Reynolds Number in a Two-Inch Pipeline.................................13 


\subsection{Introduction}

In September $1999,100,000$ to 150,000 gallons of solid/liquid waste slurry will be transferred through a pipeline from Tank 241-SY-101 (SY-101) to Tank 241-SY-102 (SY-102). The delivery system will transport SY-101 slurry, which, when diluted with water, will contain between 8.3 and 25 volume percent solids. The pipeline will be two inches in diameter and approximately 125 feet in length. It will be designed to minimize the risk of plugging by 1) having the pipeline velocity fast enough to suspend all the solids and 2) avoiding potential traps or places where potential plugging would be likely to occur. These traps include low spots and bends in the line where solids could collect. The pipeline will come vertically out of SY-101 to a high point, from which it will slope continuously down toward Tank SY-102. The waste removed from SY-101 will be diluted with water as it enters a transfer pump placed in the tank. Water jets near the inlet of the pump will mix and dilute the incoming waste. Operations personnel have proposed to deliver the waste at a temperature of approximately $50^{\circ} \mathrm{C}$, diluted 100 volume percent by water and at a flow velocity of $6 \mathrm{ft} / \mathrm{sec}$.

This report examines effects of dilution and temperature on the critical pipeline velocity, below which the solids would deposit within a horizontal pipeline. Also examined is the associated pressure drop in the pipeline. The effect of dilution ratios from 0:1 (no dilution) to 2:1 and the effect of temperatures from $18^{\circ} \mathrm{C}$ to $55^{\circ} \mathrm{C}$ have been examined. The $18^{\circ} \mathrm{C}$ case was examined as the low temperature expected due to the unlikely event of system plugging. Section 2.0 gives background on the critical velocity and pressure drop, and Section 3.0 presents the approach to the problem. Section 4.0 discusses the tank waste configuration and physical properties, Section 5.0 presents the results, and Section 6.0 gives conclusions and recommendations. Section 7 contains cited references, and supporting material can be found in the appendixes. 



\subsection{Background: Critical Velocity and Pressure Drop}

Before transporting the solid/liquid slurry in a horizontal (or nearly horizontal) pipeline, system operating parameters such as critical flow velocity and required pressure drop must be known. The pipeline flow energy must be sufficient to prevent the formation of a settled bed at the bottom of the pipe. Transient formation and erosion of a bed of settled solids causes flow and pressure fluctuations in the pipeline. It is desirable to prevent this unstable flow condition. This can be achieved by providing sufficient flow energy to maintain the solid particles in suspension. The critical velocity is the bulk average flow velocity above which full particulate suspension is maintained and the pipeline discharge pressure is stable. The pressure drop provides knowledge of the delivery system requirements. The pressure drop of the slurry flow is minimized at the critical velocity; thus the slurry pipeline transport operation is most energyefficient at this condition (Wasp 1977; Vanoni 1975).

Determination of the critical velocity depends on the flow conditions and characteristics of the slurry rheology, the solids, and the pipeline (Wasp 1977). The slurry may exhibit a range of behavior from homogeneous (vertically uniform solid concentrations) to heterogeneous (vertically nonuniform solid concentration) flow. This flow behavior affects the criteria for determining the critical velocity.

Heterogeneous flows are normally Newtonian in nature and often feature concentrations of "coarse" particles (i.e., 100 microns and larger) in which particle inertia and settling velocity are important. Solid-liquid slurries in which the solid-fluid density ratio is large can also be heterogeneous for particles of smaller size. The particles are moved along in the pipeline by the fluid, and although the fluid and solids are mixed, two phases (liquid and solid) exist as separate entities. The particles do not have a significant effect on the fluid properties; hence viscosity of the fluid carrying the solids is largely independent of solid concentration. Heterogeneous slurries require significant turbulent energy to prevent particles from depositing on the pipe bottom. These flows are therefore considered to be "deposition limited."

Homogeneous slurry flows often feature "fine" (much less than 100 microns) particles in which particle inertia and settling velocity are less important in maintaining a stable slurry flow. (Note that coarse particles can form a homogeneous flow if a pipe flow velocity is high enough to distribute solids uniformly vertically.) The fine particles tend to mix fully with the liquid flow so that the fine particles become a part of the carrying fluid, resulting in increased viscosity and altered density of the apparent carrying fluid. Some of these homogeneous slurries exhibit nonNewtonian behavior. Since particle inertia and setting velocity are small, these slurries require only a small amount of energy to prevent particles from settling. For these slurries, the velocity required to avoid solid deposition is so small that the resulting flow is often laminar. However, a laminar pipeline flow is known to deposit solids in a long and/or not totally horizontal pipeline, producing unsteady discharge and pressure drop. To avoid the formation of a settled bed and to ensure stable discharge and pressure, the velocity should be increased such that the system has made the transition from laminar to turbulent flow. Furthermore, if the slurry exhibits yield strength, the pipeline flow must overcome the yield strength to mobilize the solids. These homogeneous slurry systems are referred to as "transition limited." Of course, the purely heterogeneous and homogeneous slurry types are extreme cases, and most slurries exhibit both behaviors to some degree. 



\subsection{Approach}

\subsection{Critical Velocity Calculation}

Tingey (1994) measured rheology of SY-101 waste with and without dilution at different temperatures. The solid sizes vary from submicron to 80 microns, averaging 9.1 microns. These tests used samples that had solid concentrations similar to those expected in the slurry transfer from SY-101 to SY-102. SY-101 waste samples exhibit non-Newtonian behavior with yield strength. Because slurries can exhibit both homogeneous and heterogeneous behaviors, both the deposition and transition critical velocities were calculated, and the largest was taken as the limiting critical velocity value. The methods used to calculate the critical velocity are those developed by Thomas (1963), Wasp (1977), and Oroskar and Turian (1980). All three methods use a single particle size to calculate the critical velocity. The single particle size assumption yields conservative critical velocity predictions because "the total transport rate increases when the size gradation of sediment is broadened, and the mean size remains unchanged" (Vanoni 1975). These three methods are described in Appendix A. The methods are for solid-liquid slurries in horizontal pipelines and do not include the effect of gas on slurry behavior. SY-101 waste contains approximately 3\% gas by volume (Meyer et al. 1997; Reynolds 1993). At this low concentration and moving at several- $\mathrm{ft} / \mathrm{s}$, the bubbles in the pipeline are expected to be in dispersed or elongated form (Govier and Aziz 1987). Thus the impact of the gas on critical velocity and pressure drop is expected to be small and is neglected in the present analysis. Calculations were performed for the horizontal pipeline case only. The pipeline from SY-101 to SY-102 will not have prolonged lengths with an upward slant, so the upward slanting pipeline case is not addressed in this report.

\subsection{Pressure Drop Calculation}

Pressure drop in the pipeline was calculated at the critical velocity using an iterative method developed by Wasp (1977). The Wasp method is based on a "two-phase vehicle" concept: a mixture of the fine particles and liquid forms a carrying fluid that carries the coarser particles. Fine particles mix with the liquid and modify the fluid viscosity and density, creating a homogeneous "vehicle." Coarse particles are suspended in a heterogeneous mode within the vehicle. The overall solid concentration and size distribution affects the composition and properties of the vehicle. Increased concentration of fines increases the proportion of solids in the vehicle and its ability to suspend the coarser particles, thus decreasing the required critical velocity (Wasp 1977; Vanoni 1975).

Wasp's method is suitable for solid particles of variable size and like density. The SY-101 wastes have many different solids such as $\mathrm{Al}, \mathrm{Na}, \mathrm{Fe}$, and $\mathrm{Cr}$, including $\mathrm{NaAlO}_{2}(\mathrm{~s})$, $\mathrm{NaNO}_{3}(\mathrm{~s}), \mathrm{NaNO}_{2}(\mathrm{~s})$, and $\mathrm{NaCO}_{3} \bullet \mathrm{H}_{2} \mathrm{O}$ (s) (Reynolds 1992). The densities of crystals of these solids vary from $2.17 \mathrm{~g} / \mathrm{mL}$ of $\mathrm{NaNO}_{2}(\mathrm{~s}), 2.25 \mathrm{mg} / \mathrm{L}$ of NaCO${ }_{3} \bullet \mathrm{H}_{2} \mathrm{O}(\mathrm{s}), 2.26 \mathrm{~g} / \mathrm{mL}$ of $\mathrm{NaNO}_{3}(\mathrm{~s})$ to $4.63 \mathrm{~g} / \mathrm{mL}$ of $\mathrm{NaAlO}_{2}$ (s) (Lide 1995). Leaching tests with caustics for a composite AZ-101 and $\mathrm{AZ}-102$ sludge having $\mathrm{Al}, \mathrm{Na}, \mathrm{Fe}$ and $\mathrm{Cr}$ solids show that leaching of the sludge has little effect on the particle size distribution based on population and volume (Rapko and Wagner 1997). Whyatt et al. (1996) also states that Hanford tank waste solids are more likely in the form of aggregates rather than in individual crystal forms. Although these two studies were not done 
for the SY-101 waste, they imply that much of the SY-101 solids also exist as aggregates of many different solids rather than as individual crystals. Thus we assumed in this study that the densities of SY-101 solids (i.e., density of the aggregates) are constant $(2.30 \mathrm{~g} / \mathrm{mL})$ for all the solid sizes and types. Wasp's method for calculating pressure drop is described in Appendix B. 


\subsection{Waste Configuration and Material Properties}

Tank 241-SY-101 (SY-101) is a double-shell tank that contains 430 inches of waste. The waste within SY-101, which is a mixture of liquid, solids, and gas, is stratified, with a lower convecting layer of 345 inches and a top crust layer that, from January 1, 1998 to July 2, 1999, has grown from 50 inches to 100 inches in thickness. The convecting layer (slurry) contains roughly $25 \%$ solids and $3 \%$ gas by volume. The density of this slurry is $1.7 \mathrm{~g} / \mathrm{mL}$ at $50^{\circ} \mathrm{C}$. Within the convecting layer, the liquid density is $1.5 \mathrm{~g} / \mathrm{mL}$ at $50^{\circ} \mathrm{C}$, and the solids density is $2.3 \mathrm{~g} / \mathrm{mL}$ (Meyer et al. 1997; Reynolds 1993). Before the mixer pump was installed in SY-101 in 1993, a thick solids- and gas-containing sludge layer existed at the tank bottom.

The waste in SY-101 was sampled at a time when the temperature profiles within the tank indicated that most of the solids were settled out of the convective layer (Window C core sample) leaving solid-free liquid waste. Window $\mathrm{C}$ corresponds to a time when the thick sludge layer was present in the tank. The test samples were taken from segment 8 within the convective layer (Reynolds 1992). Tests performed on this liquid sample indicated Newtonian behavior with a temperature-dependent viscosity of $30 \mathrm{cP}$ at $50^{\circ} \mathrm{C}$ (Reynolds 1992). When the liquid waste was diluted by an equal part of $2 \mathrm{M} \mathrm{NaOH}$, the liquid viscosity was reduced to $2.9 \mathrm{cP}$ at $50^{\circ} \mathrm{C}$ (Tingey 1994). Tingey (1994) also performed yield point measurements on mixed slurry samples from SY-101 in the dilution study. In these tests, the yield point of the SY-101 undiluted sample was 60 Pascals. The yield point had been reduced to 0.7 Pascals when the sample was diluted by the equal part of $2 \mathrm{M} \mathrm{NaOH}$ (i.e., $1: 1$ dilution). Figure 1 shows the slurry yield strength versus solid concentrations (corresponding to dilution ratios) and the curve fit

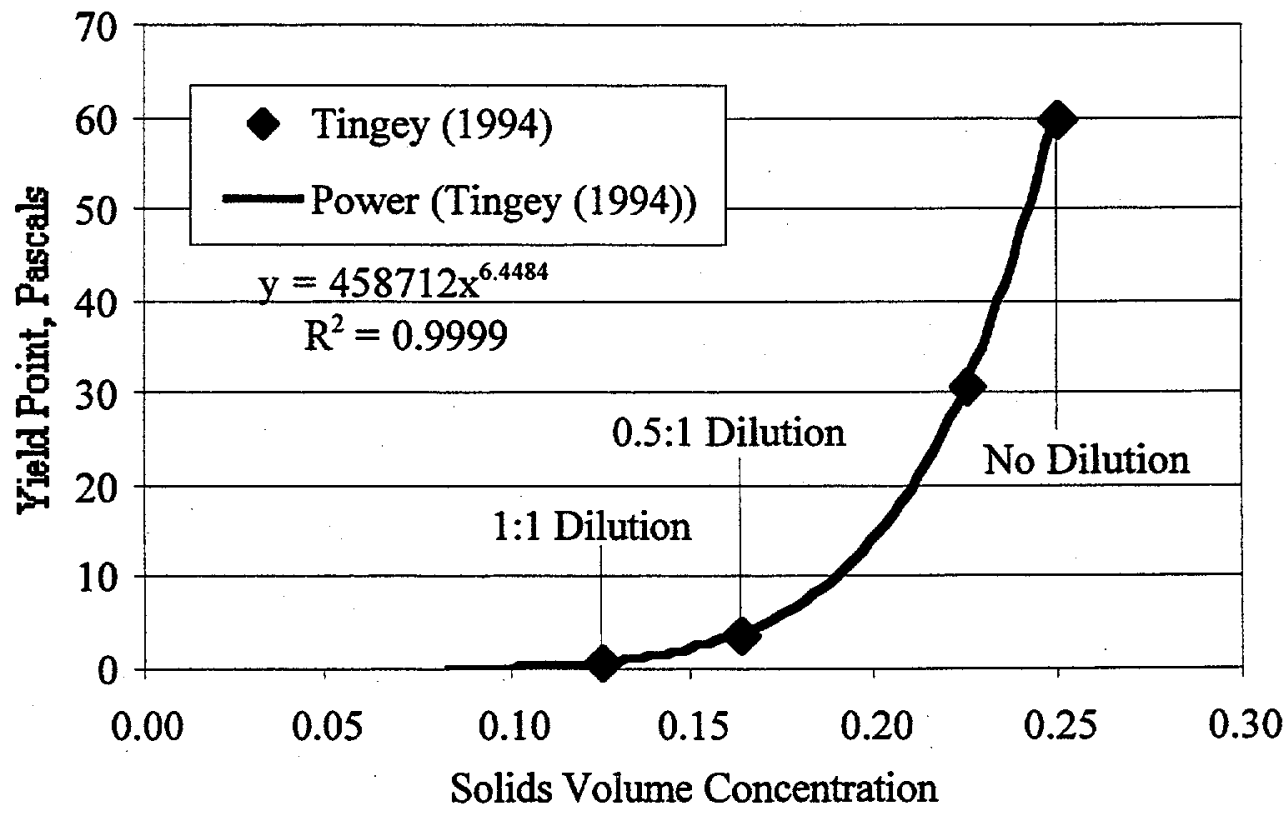

Figure 1. Estimated Yield Point versus Solid Concentration 
through these data. The yield strength of the sludge layer in Tank SY-101 was measured at 32, 50 , and $65^{\circ} \mathrm{C}$ (Reynolds 1992). A quadratic equation was fit through the sludge strength data and extrapolated to $18^{\circ} \mathrm{C}$. The sludge yield data and curve fit (dashed line) are shown in Figure 2. The yield was then scaled linearly to 60 Pascals at $50^{\circ} \mathrm{C}$ to estimate the slurry strength, as shown by the solid curve in Figure 2.

Table 1 summarizes the estimated properties used for the critical velocity and pressure drop calculations. It was assumed that the solids fraction and liquid and solid densities were independent of temperature. Liquid viscosity and yield point were temperature dependent.

A series of particle size analyses was performed on SY-101 waste (Herting et al. 1992). These measurements show the average particle diameter to be 9.1 microns with particle sizes ranging from 0.5 to 80 microns. Table 2 summarizes the most representative particle size distribution among measured values. This is the distribution used for the calculations. Preliminary critical velocity calculations were performed for a three-inch pipeline. The calculations showed little sensitivity to particle size in the 0.5 - to 80 -micron range. The analysis assumed that dilution and temperature did not affect the particle size distribution.

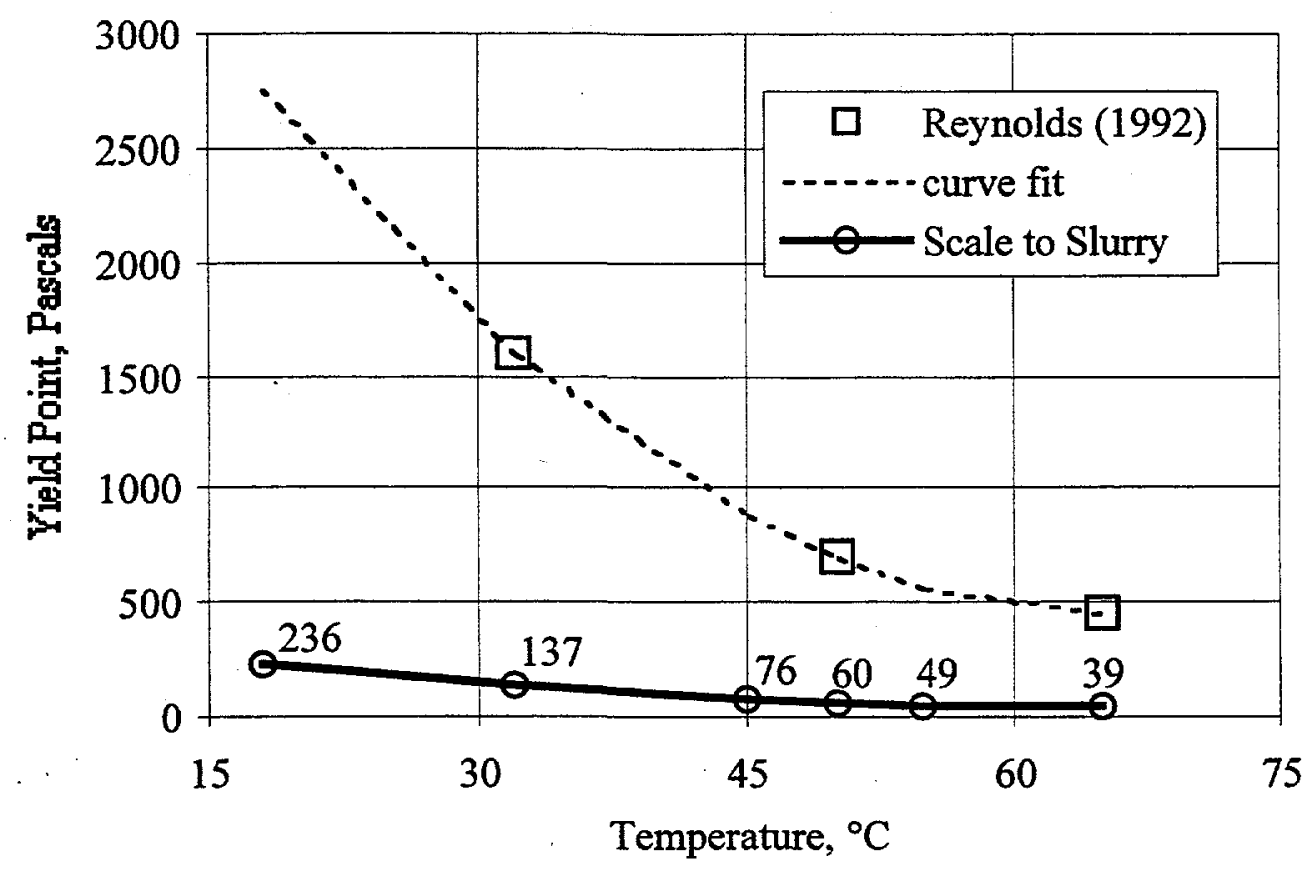

Figure 2. Estimated Yield Point of Non-Diluted Slurry versus Temperature 
Table 1. Physical Properties

\begin{tabular}{|c|c|c|c|c|}
\hline Dilution Ratio & $0: 1$ & $0.5: 1$ & $1: 1$ & $2: 1$ \\
\hline Solid Volume \% & 25 & 17 & 12.5 & 8.3 \\
\hline $\begin{array}{c}\text { Density, } \mathrm{kg} / \mathrm{m}^{3} \\
\text { Liquid } \\
\text { Slurry }\end{array}$ & $\begin{array}{l}1500 \\
1700\end{array}$ & $\begin{array}{l}1300 \\
1470\end{array}$ & $\begin{array}{l}1210 \\
1350\end{array}$ & $\begin{array}{l}1140 \\
1240\end{array}$ \\
\hline Temperature, ${ }^{\circ} \mathrm{C}$ & \multicolumn{4}{|c|}{ Liquid Viscosity, $\mathrm{cP}$} \\
\hline $\begin{array}{r}55 \\
50 \\
45 \\
18 \\
\end{array}$ & $\begin{array}{l}24 \\
30 \\
37 \\
83\end{array}$ & $\begin{array}{c}3.1 \\
3.8 \\
4.6 \\
10\end{array}$ & $\begin{array}{l}2.3 \\
2.9 \\
3.5 \\
7.7\end{array}$ & $\begin{array}{l}1.7 \\
2.0 \\
2.4 \\
5.3\end{array}$ \\
\hline Temperature, ${ }^{\circ} \mathrm{C}$ & \multicolumn{4}{|c|}{ Slurry Yield Strength, $\mathrm{Pa}$} \\
\hline $\begin{array}{l}55 \\
50 \\
45 \\
18\end{array}$ & $\begin{array}{c}49 \\
60 \\
76 \\
236\end{array}$ & $\begin{array}{l}3.6 \\
4.5 \\
5.6 \\
18\end{array}$ & $\begin{array}{c}0.56 \\
0.7 \\
0.87 \\
2.7\end{array}$ & $\begin{array}{c}0.041 \\
0.05 \\
0.064 \\
0.20\end{array}$ \\
\hline
\end{tabular}

Table 2. Particle Size Distribution

\begin{tabular}{|cc|}
\hline Particle Size, microns & Volume Fraction \\
\hline 0.75 & 0.071 \\
1.5 & 0.187 \\
2.5 & 0.134 \\
3.5 & 0.131 \\
4.5 & 0.101 \\
5.5 & 0.066 \\
6.5 & 0.046 \\
7.5 & 0.011 \\
9.0 & 0.014 \\
11.5 & 0.041 \\
21.5 & 0.000 \\
31.0 & 0.187 \\
33.5 & 0.011 \\
Average $=9.1$ microns & Sum $=1.0$ \\
\hline
\end{tabular}





\subsection{Results}

The critical velocities and pressure drops for the two-inch pipeline were estimated at four dilution ratios (water:SY-101 waste) of $0: 1,0.5: 1,1: 1$, and $2: 1$; and at four temperatures of 18 , 45,50 and $55^{\circ} \mathrm{C}$. The calculated critical velocities are summarized in Table 3. The Newtonian, deposition-limited, critical velocities were calculated using Equations (A.1) and (A.4) (see Appendix A). Values shown in Table 3 are the larger of those calculated by the two methods. For the non-diluted case (dilution of $0: 1$ ), critical velocities calculated by these equations produced laminar pipe flow. In this case, the velocity was increased such that the Reynolds number had a value of 3000 to ensure fully turbulent flow. For the non-Newtonian slurry with yield stress assumption, the corresponding critical velocity was determined by Equation (A.8). The applicable critical velocity for a given dilution and temperature should be taken as the larger of the Newtonian and non-Newtonian critical velocity values given in Table 3.

Critical velocity varied from $1.5 \mathrm{ft} / \mathrm{sec}$ for the $2: 1$ dilution at $18^{\circ} \mathrm{C}$ to $23 \mathrm{ft} / \mathrm{sec}$ at the $0: 1$ dilution at $18^{\circ} \mathrm{C}$. Because the no-dilution case requires the critical velocities to be $11-23 \mathrm{ft} / \mathrm{sec}$, the SY-101 waste should be diluted before transferring it through the two-inch pipeline. During normal system operation, the two-inch pipeline system will transfer the 1:1 diluted waste at $50^{\circ} \mathrm{C}$. Thus the temperature would remain constant and therefore would not affect the slurry properties during the pipeline transfer operation. For this operating temperature the estimated critical velocities, except in the no-dilution case, are between 1.4 and $3.5 \mathrm{ft} / \mathrm{sec}$. For the $1: 1$ dilution case, the critical velocity at all four temperatures ranges between 1.4 and $1.6 \mathrm{ft} / \mathrm{sec}$. These values are all within the desired operating flow velocity of $6 \mathrm{ft} / \mathrm{sec}$.

The Reynolds number and the pressure drops associated critical velocities of Table 3 at $50^{\circ} \mathrm{C}$ are listed in Table 4. The tabulated Reynolds numbers show the all these pipe flows are turbulent. The pressure drop for the $1: 1$ dilution at $50^{\circ} \mathrm{C}$ is only $0.008 \mathrm{ft} / \mathrm{ft}$, or about $2 \mathrm{ft}$ of pressure drop over a 250 -ft equivalent straight pipe length.

Table 3. Estimated Critical Velocities in a Two-Inch Pipeline

\begin{tabular}{|c|c|c|c|c|}
\hline Dilution Ratio & $\begin{array}{c}0: 1 \\
\text { (No dilution) }\end{array}$ & $0.5: 1$ & $1: 1$ & $2: 1$ \\
\hline Temperature, ${ }^{\circ} \mathrm{C}$ & \multicolumn{4}{|c|}{ Newtonian Critical Velocity, ft/sec } \\
\hline 55 & 6.6 & 1.4 & 1.6 & 1.6 \\
\hline 50 & 8.3 & 1.4 & 1.5 & 1.6 \\
\hline 45 & 10 & 1.4 & 1.5 & 1.6 \\
\hline 18 & 23 & 1.3 & 1.4 & 1.5 \\
\hline Temperature, ${ }^{\circ} \mathrm{C}$ & \multicolumn{4}{|c|}{ Non-Newtonian Critical Velocity, $\mathrm{ft} / \mathrm{sec}$} \\
\hline 55 & 11 & 3.1 & 1.3 & 0.36 \\
\hline 50 & 12 & 3.5 & 1.4 & 0.40 \\
\hline 45 & 13 & 3.9 & 1.6 & 0.45 \\
\hline 18 & 23 & 6.8 & 2.8 & 0.79 \\
\hline
\end{tabular}


Table 4. Estimated Pressure Drops and Reynolds Number in a Two-Inch Pipeline

\begin{tabular}{|c|c|c|c|c|}
\hline Dilution Ratio & $\begin{array}{c}0: 1 \\
\text { (No dilution) }\end{array}$ & $0.5: 1$ & $1: 1$ & $2: 1$ \\
\hline \multicolumn{5}{|c|}{ Newtonian Slurry } \\
\hline $\begin{array}{c}\text { Reynolds } \\
\text { Number }\end{array}$ & 3000 & 5200 & 7500 & 11,400 \\
\hline $\begin{array}{c}\text { Pressure Drop, } \\
\mathrm{ft} / \mathrm{ft}\end{array}$ & 0.32 & 0.009 & 0.008 & 0.007 \\
\hline \multicolumn{5}{|c|}{ Non-Newtonian Slurry } \\
\hline $\begin{array}{c}\text { Reynolds } \\
\text { Number }\end{array}$ & 2100 & 2100 & 2100 & 2100 \\
\hline $\begin{array}{c}\text { Pressure Drop, } \\
\mathrm{ft} / \mathrm{ft}\end{array}$ & 0.57 & 0.037 & 0.0036 & 0.0008 \\
\hline
\end{tabular}




\subsection{Conclusions and Recommendations}

The effects of temperature and dilution on the critical velocity have been analyzed for pipeline transfer of waste slurry from Tank SY-101 to Tank SY-102 through a two-inch pipeline. The analyses have shown that the SY-101 slurry should be diluted with water prior to delivery. A dilution ratio of $1: 1$ is desirable and would allow the waste to be delivered at a critical velocity of $1.5 \mathrm{ft} / \mathrm{sec}$. Because the system will be operated at a flow velocity of $6 \mathrm{ft} / \mathrm{sec}$, this velocity will be sufficient to maintain a stable slurry delivery through the pipeline. Pressure drop at the critical velocity would be approximately $2 \mathrm{ft}$ for a $125 \mathrm{ft}$ pipeline (or 250 -ft equivalent straight pipeline). At $6 \mathrm{ft} / \mathrm{sec}$, the pressure drop would be $20 \mathrm{ft}$ over a 250 - $\mathrm{ft}$ equivalent straight pipeline. 



\subsection{References}

Govier GW and K Aziz. 1987. "The Flow of Complex Mixtures in Pipes." Robert E. Krieger Publishing Company, Malabar, Florida.

Herting DL, DB Bechtold, BE Hey, BD Keele, L Jensen, and TL Welsh. 1992. "Laboratory Characterization of Samples Taken in December 1991 (Window E) From Hanford Waste Tank 241-SY-101." WHC-SD-WM-DTR-026 Rev. 0. Westinghouse Hanford Company, Richland, Washington.

Lide DR. 1995. CRC Handbook of Chemistry and Physics. CRC Press, New York.

Meyer PA, ME Brewster, SA Bryan, G Chen, LR Pederson, CW Stewart, and G Terrones. 1997. Gas Retention and Release Behavior in Hanford Double-Shell Waste Tanks. PNNL-11536

Rev. 1, Pacific Northwest National Laboratory, Richland, Washington.

Oroskar AR and RM Turian. 1980. "The Critical Velocity in Pipeline Flow of Slurries." $A I C h E$ Journal, Vol. 26, No. 4.

Rapko BM and MJ Wagner. 1997. "Caustic Leaching of Composite AZ-101/AZ-102 Hanford Tank Sludge." PNNL-11580, Pacific Northwest National Laboratory, Richland, Washington.

Reynolds DA. 1992. "Tank 101-SY Window C Core Sample Results and Interpretation." WHC-EP-0589, Westinghouse Hanford Co., Richland, Washington.

Reynolds DA. 1993. "Tank 101-SY Window E Core Sample: Interpretation of Results." WHC-EP-0628, Westinghouse Hanford Co., Richland, Washington.

Thomas DG. 1963. "Non-Newtonian Suspensions." Part I, Ind. Eng. Chem., Vol. 55, pp. 18-29.

Tingey JM, PR Bredt, and EH Shade. 1994. "The Effects of Heating and Dilution on the Rheological and Physical Properties of Tank 241-SY-101 Waste." PNL-10198, Pacific Northwest National Laboratory, Richland, Washington.

Vanoni VA. 1975. "Sedimentation Engineering." ASCE -Manuals and Reports on Engineering Practice-No. 54. New York.

Wasp EJ. 1977. "Solid-Liquid Flow Slurry Pipeline Transportation." Trans Tech Publications.

Whyatt GA, RJ Serne, SV Mattigold, Y Onishi, MR Powell, JH Westik Jr, LM Liljegren, GR Golcar, KP Recknagle, PM Doctor, VG Zhirnov, and J Dixon. 1996. Potential for Criticality in Hanford Tanks Resulting from Retrieval of Tank Waste. PNNL-11304, Pacific Northwest National Laboratory, Richland, Washington.

Zandi I and G Govatos. 1967. "Heterogeneous Flow of Solids in Pipelines." J. Hydr. Div. ASCE, 93:HY3, Proc. Paper 5244, pp. 145-159. 
Appendix A

Methods Used to Calculate the Critical Velocity 


\section{Appendix A}

\section{Methods Used to Calculate the Critical Velocity}

We used the methods of two investigators to estimate the critical deposition velocity. A correlation developed by Oroskar and Turian (1980) was built on the earlier work of several authors and accounted for dissipation of turbulent energy. Regressional analysis on 350 data points yielded their correlation for the critical deposition velocity as

$$
\frac{U_{c}}{\sqrt{g d(S-1)}}=1.85 C_{v}^{0.1536}\left(1-C_{v}\right)^{0.3564}\left(\frac{D}{d}\right)^{0.378} \operatorname{Re}_{p}^{0.09} x^{0.3}
$$

Here $U_{c}$ is the critical velocity, $C_{v}$ is the solid volume fraction, $D$ is the pipe diameter, $d$ is the average particle diameter, $S$ is the solid/liquid density ratio, and $\operatorname{Re}_{\mathrm{p}}$ is the Reynolds number defined as

$$
\operatorname{Re}_{p}=\frac{\rho_{L} D \sqrt{g d(S-1)}}{\mu_{L}}
$$

In the correlation, $\mathrm{x}$ is the correction factor for dissipation of turbulent energy, which can be written as

$$
\mathrm{x}=\frac{4}{\pi} \gamma \exp \left(\frac{-4 \gamma^{2}}{\pi}\right)+\frac{\sqrt{\pi}}{2} \operatorname{erfc}\left(\frac{2 \gamma}{\sqrt{\pi}}\right)
$$

where $\gamma$ is the ratio of particle settling velocity to critical velocity. In the calculations, $\mathrm{x}$ is determined for a range of $\gamma$ and is roughly 0.96 .

Wasp's method modified the Durand relation (Durand 1952) to include the effect of particle concentration and mean particle diameter (Wasp 1977):

$$
\mathrm{U}_{\mathrm{c}}=3.116 \mathrm{C}_{\mathrm{v}}^{0.186}\left[2 \mathrm{gD}\left(\frac{\rho_{\mathrm{s}}-\rho_{1}}{\rho_{1}}\right)\right]^{\frac{1}{2}}\left(\frac{\mathrm{d}}{\mathrm{D}}\right)^{\frac{1}{6}}
$$

These two methods give similar values for the deposition critical velocity. It was also confirmed that they produce conservative (larger) critical velocity values than the methods of other authors (e.g., Wani 1982; Zandi and Govatos 1967).

The non-Newtonian slurry with yield strength requires the "transition limited" approach to determine the critical velocity, as discussed in Section 2 of the main report. The following method (Wasp 1977) was chosen for this case:

$$
U_{c}=\sqrt{\frac{\operatorname{Re}}{6}} \sqrt{\frac{\tau_{o}}{\rho}}
$$


where

$$
\operatorname{Re}=\frac{\mathrm{U}_{\mathrm{c}} \mathrm{D} \rho}{\mu_{\mathrm{eff}}}
$$

In the above equation, the effective viscosity, $\mu_{\mathrm{eff}}$, in the Reynolds number $\mathrm{Re}$ was defined as (Wasp 1977):

$$
\mu_{\text {eff }}=\frac{\tau_{o} D}{6 U_{c}}
$$

where $\tau_{\mathrm{o}}$ is the material yield strength. Wasp assigned a pipeline Reynolds number of 2100 to have transition to turbulence. Thus, Equation A.5 becomes

$$
U_{c}=19 \sqrt{\frac{\tau_{o}}{\rho}}
$$

\section{References}

Durand R. November 1952. "Hydraulic Transport of Coal and Solid Materials in Pipes." Proceedings of a Colloquium on the Hydraulic Transport of Coal, pp. 39-52. National Coal Board, London.

Oroskar AR and RM Turian. 1980. "The Critical Velocity in Pipeline Flow of Slurries." AIChE Journal, Vol. 26, No. 4.

Wani CA. 1982. "Critical Velocities in Multisize Particle Transportation Through Horizontal Pipes.” Journal of Pipelines, Vol. 2, pp. 57-62.

Wasp EJ. 1977. Solid-Liquid Flow Slurry Pipeline Transportation. Trans Tech Publications.

Zandi I and G Govatos. 1967. "Heterogeneous Flow of Solids in Pipelines." J. Hydr. Div. ASCE, 93:HY3, Proc. Paper 5244, pp. 145-159. 
Appendix B

Pressure Drop Calculation-the Wasp Method 


\section{Appendix B}

\section{Pressure Drop Calculation - the Wasp Method}

A slurry flow is considered to be homogeneous when the solid concentration (C) at the distance $y=0.08 \mathrm{D}$ from the top of a horizontal pipe is at least $80 \%$ of the concentration at the pipe centerline $\left(\mathrm{C}_{\mathrm{A}}\right)$. From experimental data (Ismail 1952) for the particular cases of $y=0.08 \mathrm{D}$ and $y=0.92 \mathrm{D}$, Wasp gives the relationship for concentration as

$$
\log _{10} \frac{C}{C_{A}}=\left(\frac{-1.8 w}{\beta \mathrm{xu}^{*}}\right)
$$

where $w$ is the particle settling velocity, $\beta$ is a constant for a given particle size, $x$ is the Von Karman constant, and $u^{*}$ is the friction velocity. Values of $\beta$ range from 1.0 for fine particles of sub-100- $\mu \mathrm{m}$ diameter, to 1.3 for coarse particles of $0.1 \mathrm{~mm}$ size. The Von Karman constant is 0.4 for clear fluid and decreases with particle concentration. The calculations used $\beta=1.0$ and $x$ $=0.4$. The friction velocity is given as

$$
\mathrm{u}^{*}=\mathrm{U} \sqrt{\frac{\mathrm{f}}{2}}
$$

where $\mathrm{U}$ is the bulk flow velocity, and $\mathrm{f}$ is the slurry friction factor from the Moody diagram.

The total pressure drop is the sum of the vehicle friction loss and the friction loss due to the heterogeneity of the remaining (coarser) solids. The friction factor used for the vehicle portion is found using the Moody diagram, which in the turbulent regime is computed by the following:

$$
\frac{1}{\sqrt{f}}=4 \log \frac{D}{2 \varepsilon}+3.48-4 \log \left(1+9.35 \frac{D}{2 \varepsilon \operatorname{Re} \sqrt{f}}\right)
$$

Then the friction loss comes from the standard relation

$$
\Delta \mathrm{p}_{\text {veh }}=\frac{\mathrm{h}_{\mathrm{L}}}{\mathrm{L}}=4 \frac{\mathrm{f}}{\mathrm{D}} \frac{\mathrm{U}_{\mathrm{c}}^{2}}{2 \mathrm{~g}}
$$

The "bed friction loss" $\left(\Delta \mathrm{p}_{\text {bed }}\right)$ is the "overpressure," compared to that of pure water, due to the heterogeneity of the remaining solids exclusive of the vehicle. It is computed using Durand's equation (Durand 1953):

$$
\Delta \mathrm{p}_{\text {bed }}=82\left(\Delta \mathrm{p}_{\text {water }}\right) \mathrm{C}_{\mathrm{v}, \text { bed }}\left(\frac{\mathrm{gD}(\mathrm{s}-1)}{\mathrm{U}_{\mathrm{c}}^{2} \sqrt{\mathrm{C}_{\mathrm{D}}}}\right)^{1.5}
$$


Here $\Delta p_{\text {water }}$ is calculated using (B.4). The result of (B.5) is in terms of a head of water; therefore the vehicle friction loss must be converted from $\mathrm{ft}$-slurry/ $\mathrm{ft}$ to $\mathrm{ft}$-water/ft before adding to the bed friction loss.

The vehicle is determined using an iterative mass balance on the vehicle and heterogeneous portion of the solids. Convergence is achieved when the associated pressure drop is unchanging.

\section{References}

Durand R. November 1952. "Hydraulic Transport of Coal and Solid Materials in Pipes." Proceedings of a Colloquium on the Hydraulic Transport of Coal, pp. 39-52. National Coal Board, London.

Ismail HM. 1952. "Turbulent Transfer Mechanism and Suspended Sediment in Closed Channels." Trans. ASCE, Vol. 117, pp. 409-447 


\section{Distribution}

No. of

Copies

Offsite

2 DOE Office of Scientific and

Technical Information

\section{Onsite}

2 DOE Richland Operations Office

D. H. Irby

C. A. Groendyke

S7-54

S7-54

18 PHMC Team

J. W. Bailey

S2-48

W. B. Barton

R2-11

R. E. Bauer

J. R. Biggs

G1-54

J. R. Buchanon

M. L. Carlisle

M. F. Erhart

S. D. Estey
T4-08

G1-54

S7-07

R1-56

R2-11
No. of

Copies
J. M. Grigsby
S7-73
C. E. Hanson
G1-54
G. D. Johnson
S7-14
N. W. Kirch
R2-11
C. E. Leach
R1-49
K. L. Morris
G1-54
W. J. Powell
G1-54
R. E. Raymond
G1-54
S. W. Shaw
G1-54
LMHC Correspondence Control
H7-09

33 Pacific Northwest National Laboratory

S. Q. Bennett

J. W. Brothers (3)

K7-90

Carl W. Enderlin

K5-22

W. L. Kuhn

K7-15

P. A. Meyer

K $7-15$

Y. Onishi (5)

K7-15

K7-15

K. P. Recknagle (15)

K7-15

C. W. Stewart

K7-15

Information Release (5) 